\title{
PENEGAKAN HUKUM YANG DILAKUKAN PERSEORANGAN KEPADA ANAK DI BAWAH UMUR
}

\author{
Oleh \\ Annie Myranika dan Danie1*)
}

\section{Abstrak}

Tindak Pidana Human Trafficking yang dilakukan perseorangan terhadap anak di bawah umur terjadi karena faktor-faktor seperti masalah keuangan, kurangnya pendidikan dan pengembangan anak yang mendorong anak tersebut turun ke jalan demi membantu perekonomian keluarga. Permasalahan dalam Penelitian ini adalah bagaimanakah Pertimbangan hakim terhadap Tindak Pidana Perdagangan Anak dibawah umur oleh perseorangan berdasarkan Putusan Nomor 1608/pid.sus/2016 /PN.Tng Tahun 2017 dan Apakah putusan Pengadilan Negeri Tangerang Nomor 1608/pid.sus/2016/PN.Tng Tahun 2017 tentang Tindak Pidana Perdagangan Anak dibawah umur oleh perseorangan sudah memenuhi unsur keadilan. Adapun sifat penelitian deskriptif analistis serta landasan Hukumnya mengacu kepada Undang-Undang TPPO, Undang-Undang Perlindungan Anak, dan Undang-Undang ketenagakerjaan.

\section{Kata Kunci : Hukum Pidana, Perlindungan Anak}

\section{A.PENDAHULUAN}

Negara Kesatuan Republik Indonesia adalah Negara yang berdasar atas hukum, Maka kedudukan hukum harus ditempatkan segala-galanya. Anak adalah anugerah dari Tuhan Yang Maha Esa sebagai generasi penerus bangsa yang masih dalam tahap tumbuh dan berkembang, baik fisik maupun mental.

Resesi ekonomi yang berkepanjangan merupakan salah satu faktor penggerak "arus anak turun ke jalan". Secara garis besar keberadaan anak di jalan dapat dikelompokkan menjadi dua, salah satu

*) Penulis adalah Dosen Fakultas Hukum Universitas Islam Syekh Yusuf di antaranya adalah anak jalanan yang masih memiliki Orang tua. ${ }^{1}$

Jika ditelaah lebih mendalam, sebenarnya banyak faktor yang memicu anak untuk bekerja disaat mereka seharusnya memperoleh pendidikan yang layak dan menikmati masa-masa yang menyenangkan sebagai anak anak. Terutama ialah faktor ekonomi yang semakin mempersulit jalan mereka untuk tetap hidup.

Hal tersebutlah yang kemudian dimanfaatkan oleh perseorangan atau individu dalam memperoleh keuntungan materil dengan cara memperkerjakan anak di bawah umur dengan cara meng-

1 Endang Sumiarni, "Perlindungan Anak Jalanan ditinjau dari aspek HAM, Hukum, Psikologi, dan Prakteknya" di FH-UAJY. Diskusi Panel, Sabtu, 1 Desember 2001. 
eksploitasi anak tersebut untuk bekerja dengan cara perekrutan, pengangkutan, penampungan dan menge-sampingkan hak yang harus didapat anak dalam bekerja, perilaku tersebut dapat disebut perdagangan orang (human trafficking). ${ }^{2}$

Perdagangan orang (human trafficking) merupakan bentuk perbudakan secara modern, Terjadi baik dalam tingkat nasional dan internasional. Dengan berkembangnya teknologi informasi, komunikasi dan transformasi, maka modus kejahatan perdagangan manusia semakin canggih. "Perdagangan orang/manusia bukan kejahatan biasa (extra ordinary), terorganisis (organized), dan lintas negara (transnational), sehingga dapat dikategorikan sebagai Transnational Organized Crime (TOC). ${ }^{3}$

Kejahatan ini terjadi karena tidak ada penghormatan terhadap martabat kemanusiaan. Manusia dipandang sebagai barang yang bisa ditentukan harganya tanpa persetujuannya, dibawa, dikumpulkan, dikurung, dan ditempatkan tanpa mempertimbangan kebutuhannya sebagai manusia. ${ }^{4}$

Di Indonesia upaya untuk menangani masalah perdagangan orang (human trafficking) telah diatur dalam UndangUndang Nomor 21 Tahun 2007 tentang Pemberantasan Tindak Pidana Perdagangan Orang baik usia dewasa maupun anak. Undang-undang ini diharapkan dapat menjadi instrumen penegakan hukum dalam menjerat pelaku tindak pidana perdagangan orang sekaligus melindungi hak-hak korban.

Selain itu di Indonesia juga terdapat Undang-Undang No. 35 Tahun 2014 ten-

2 Supriyadi Widodo Eddyono. Perdagangan manusia dalam rancagan KUHP, ELSAM Lembaga Studi Dan Advokasi Masyarakat, 2005, hlm. 2

3 Ibid, hlm 3

4 Candra Muzaffar dkk. Human's wrong: Rekor Buruk Dominasi Barat atas HAM, Yogyakarta: Pilar Media, 2007, hlm. 401. tang perubahan atas Undang-Undang No. 23 Tahun 2002 tentang perlindungan anak. Dimana dalam Undang-Undang ini hak dan perlindungan terhadap seorang anak sangat diharapkan demi terhindarnya anak dari pada kejahatan-kejahatan yang melibatkan anak untuk menjadi korbannya. ${ }^{5}$

Aparat penegak hukum mempunyai tugas untuk mencegah permasalahan perdagangan anak dengan menggunakan, perundang undangan yang ada pada saat ini. Upaya pencegahan dan penanggulangan permasalahan ini dilakukan di tingkat internasional, regional, dan lokal, dengan melakukan kerjasama terhadap instansi terkait, dalam hal ini pihak kepolisian. Aparat penegak hukum harus bisa bekerja sama dan bekerja keras guna menanggulangi permasalahan perdagangan anak.

Aparat penegak hukum di tingkat lokal yakni kepolisian sebagai penyidik harus bisa menerapkan dengan tepat peraturan perundang undangan yang ada di Indonesia untuk menjerat pelaku agar bisa memberikan efek jera terhadap pelaku tindak pidana perdagangan anak. Peraturan yang terkait dalam permasalahan perdagangan anak adalah UndangUndang No 21 tahun 2007 tentang Pemberantasan Tindak Pidana Perdagangan Orang (selanjutnya disebut UndangUndang Perdagangan Orang). Selain itu aparat terkait harus dengan giat melakukan kegiatan guna mencegah permasalahan perdagangan anak. ${ }^{6}$

Komisi Perlindungan Anak Indonesia, disingkat KPAI, adalah lembaga independen Indonesia yang dibentuk berdasarkan Undang-Undang Nomor 23 Tahun 2002 tentang Perlindungan Anak dalam rangka

5 http://www.kpai.go.id/diakses tanggal 12 maret 2018 jam 13.55 WIB

6 L.M Lapian Gandi dan Geru H Hetty. Trafficking Anak dan Wanita, Jakarta: Rineka Cipta, 2005 hlm 134. 
meningkatkan efektifitas penyelenggaraan perlindungan anak. Keputusan Presiden Nomor 36/1990, 77/2003 dan 95/M/ 2004 merupakan dasar hukum pembentukan lembaga ini. ${ }^{7}$

Undang-Undang tersebut berubah dan telah disesuaikan oleh UndangUndang No 35 Tahun 2014 tentang perlindungan anak, dan Komisi Perlindungan Anak Indonesia mempunyai tugas dan fungsi yang dijelaskan dalamPasal 74 Undang-Undang 35 Tahun 2014 yaitu :

"Dalam rangka meningkatkan efektivitas penyelenggaraan perlindungan anak, maka dibentuk Komisi Perlindungan Anak Indonesia yang bersifat independen".

Berdasarkan pasal tersebut di atas, mandat KPAI adalah mengawal dan mengawasi pelaksanaan perlindungan anak yang dilakukan oleh para pemangku kewajiban perlindungan anak sebagaimana ditegaskan dalam Pasal 20 UndangUndang No 35 Tahun 2014 yakni :

"Negara, Pemerintah, Pemerintah Daerah, Masyarakat, Keluarga, dan Orang Tua atau Wali berkewajiban dan bertanggung jawab terhadap penyelenggaraan"8

Pekerja anak diyakini akan terus bertambah menyusul krisis ekonomi yang tidak kunjung usai sejak tahun 1997. Kecenderungan meningkatnya jumlah pekerja anak dapat dilihat dari meningkatnya anak jalanan setiap tahunnya. Dalam banyak kasus, anak-anak yang masuk ke pasar kerja merupakan rasionalisasi untuk memenuhi kebutuhan ekonomi keluarga yang dilanada kemiskinan.

Sumbangan perkerja anak untuk ekonomi keluarga tidak kecil. Menurut

7 https://id.wikipedia.org/wiki/Komisi_Perlind ungan_Anak_Indonesia, diakses tan-ggal 12 Maret 2018 jam 14.00 WIB.

8 http://www.kpai.go.id/profil/, diakses tanggal 12 Maret 2018 jam 14.15 WIB laporan yang diungkap PBB, pekerja anak rata-rata member sumbangan 20 persen bagi ekonomi keluarga. Bahkan, berdasarkan hasil survey yayasan pendidikan Indonesia, terungkap bahwa 100 persen anak-anak bekerja atas kemauan sendiri. Hal yang menarik, anak-anak juga merasakan manfaat selama mereka bekerja.

Dalam tindak pidana perdagangan orang yang dilakukan perseorangan kepada anak dibawah umur seharusnya menjadi hal yang dinilai semakin kritis bagi anak-anak di Indonesia, dikarenakan anak-anak berusia dibawah umur tidak seharusnya bekerja layaknya seperti orang dewasa melainkan hak dan kewajiban si anak ialah memperoleh pendidikan yang layak dan waktu bermain yang cukup. Adapun permasalahan dalam penelitian ini adalah :

1. Bagaimanakah Pertimbangan Hakim terhadap Tindak Pidana Perdagangan Anak di bawah umur oleh perseorangan berdasarkan putusan Nomor 1608/pid.sus/2016/PN.Tng Tahun 2017 ?

2. Apakah putusan Pengadilan Negeri Tangerang Nomor 1608/pid.sus/2016 /PN.Tng Tahun 2017 tentang Tindak Pidana Perdagangan Anak dibawah umur oleh perseorangan sudah memenuhi unsur keadilan?

\section{B. PEMBAHASAN}

1. Pertimbangan Hakim dalam menjatuhkan Tindak Pidana dalam kasus Tindak Pidana Perdagangan Orang yang dilakukan perseorangan kepada anak di bawah umur berdasarkan Putusan Nomor 1608/PID.SUS/2016/PN.TNG

Setiap Hakim atau Majelis Hakim dalam memimpin jalannya sebuah persidangan memiliki bahan pertimbangan dalam menjatuhkan putusan atau vonis dalam suatu kasus yang akan diadilinya. 
Dalam kasus Tindak Pidana Perdagangan Orang yang dilakukan perseorang kepada anak di bawah umur oleh Terdakwa T, Hakim dalam putusannya Mengadili bahwa Perbuatan Terdakwa itu tidak merupakan suatu tindak Pidana dan Melepaskan Terdakwa T dari segala tuntutan Hukum.

Karena tidak terbukti adanya unsur Tindak Pidana Perdagangan Orang dan Orang Tua maupun Anak yang disuruh berdagang walaupun masih dibawah umur menyetujui. Unsur menyetujui ini menyebabkan terdakwa lepas dari tuntutan Hukum.

Hal tersebut sangat bertolak belakang dengan tuntutan JPU yang didukung oleh keterangan korban, saksi dan saksi ahli. Putusan tersebut terjadi karena Hakim dalam pertimbangannya beranggapan bahwa tindakan saksi CN dan DD, berjualan cobek didasari atas keinginannya sendiri dan juga melakukan pembelajaran melalui model yaitu lingkungan sosial.

Menurut analisa penulis, bahwa sudah jelas tertera dalam pasal 26 Undangundang Nomor 21 tahun 2007 tentang Pemberantasan Tindak Pidana Perdagangan Orang yang menyatakan :

"Persetujuan Korban perdagangan orang tidak menghilangkan penuntutan tindak pidana perdagangan orang"

Hal itulah seperti yang tertuang dalam pasal tersebut yang membuat penulis kurang setuju oleh pertimbangan Hakim mengenai kasus yang dialami oleh $\mathrm{CN}$ dan DD.

Dan dalam kasus tersebut hal yang selanjutnya menjadi pertimbangan Hakim mengadili bahwa Perbuatan Terdakwa itu tidak merupakan suatu tindak Pidana karena Sdr. CN dan DD tidak mengalami kekerasan fisik ataupun keadaan traumatis karena akibat berjualan cobek dan hasil daripada mereka berjualan cobek tersebut dapat membantu taraf ekonomi keluarga mereka dan hasilnya untuk orang tua mereka.
Menurut penulis bahan pertimbangan hakim tersebut ialah keliru karena dalam kenyataannya sdr CN dan DD bekerja berjualan cobek sebagai Anak di bawah umur dan diperlakukan oleh terdakwa sudah melebihi hal yang seharusnya dilakukan anak dalam bekerja. Hal ini bertentangan dengan hak-hak yang seharusnya didapat oleh anak yang tertuang dalam pasal 69 sampai dengan 75 UU No 13 Tahun 2003 tentang ketenagakerjaan, diantaranya :

1. Jam kerja

2. Kesehatan dan keselamatan anak dalam bekerja

3. Kondisi dan lingkungan kerja tidak mengganggu perkembangan fisik, mental, sosial, dan waktu sekolah.

4. Dan lain-lain seperti yang tertuang dalam Pasal 69 sampai dengan Pasal 75 Undang-undang Nomor 13 Tahun 2003 tentang ketenagakerjaan

Oleh Karena itumenurut penulis hakhak yang seharusnya di dapat oleh korban dikesampingkan oleh terdakwa, sehingga tidak mungkin dapat dikatakan bahwa sdr Cepi Nurjaman dan Dendi Darmawan tidak mengalami keadaan traumatis, tetapi mereka memiliki pengalaman yang buruk yang dapat mempengaruhi pola pikir, perkembangan moral, dan tujuan hidup dari pada Korban.

Walaupun mereka membantu perekonomian keluarga pada saat itu, menurut penulis pertimbangan Hakim yang beranggapan bahwa sdr Cepi Nurjaman dan Dendi Darmawan itu membantu taraf ekonomi keluarga ialah tidak baik, oleh karena itu Seharusnya Hakim harus memikirkan perkembangan dalam diri anak itu juga tersebut.

Karena dalam perkembangan anak sangat perlu diperhatikan oleh orang tua, masyarakat, pemerintah maupun para stakeholders yang berpartisipasi bahwa dalam perkembangan anak itu yang sehingga dalam hal apapun perlindungan anak itu harus dijaga intinya seperti 
tertuang dalam pasal 1 ayat 2 UndangUndang nomor 35 Tahun 2014 tentang perubahan atas Undang-Undang Nomor 23 Tahun 2002 tentang Perlindungan Anak yang berisi :

"Perlindungan Anak adalah segala kegiatan untuk menjamin dan melindungi anak dan hak-haknya agar dapat hidup, tumbuh, berkembang dan berpartisipasi secara optimal sesuai dengan harkat dan martabat kemanusiaan, serta mendapat perlindungan dari kekerasan dan diskriminasi".

Hal-hal seperti yang tertera di atas lah yang membuat penulis ingin mencoba menganalisa pertimbangan Hakim dalam putusan tersebut. Demikian analisa yang kiranya dapat penulis tuangkan dalam penelitian ini.

\section{Analisis Penerapan Hukuman Ter- hadap Pelaku Tindak Pidana Perda- gangan Orang yang Dilakukan Per- seorangan Kepada Anak di Bawah Umur berdasarkan putusan nomor : 1608/PID.SUS/2016/PN.TNG.}

Bahwa menurut dalam kasus yang penulis teliti, Penerapan hukuman Oleh Majelis Hakim dalam Mengadili Perbuatan Terdakwa itu tidak merupakan suatu tindak Pidana dan Melepaskan Terdakwa $\mathrm{T}$ dari segala tuntutan Hukum yang di dakwakan oleh Jaksa Penuntut Umum (JPU) ialah sudah sesuai dengan Hukum yang berlaku.

Penerapan tersebut sudah sesuai karena bukan ranah hukum pidana dan tidak memenuhi unsur eksploitasi terhadap anak dibawah umur tersebut. Namun perlu diketahui juga ada pertimbangan Hakim yang perlu ditinjau ulang dan dikaitkan ke dalam undangundang yang berlaku dalam kasus tersebut.

Menurut Penulis jika Perkara tersebut bukanlah masuk ke ranah kasus Tindak Pidana Perdagangan Orang melainkan ke
Ranah Hukum Ketenagakerjaan, karena adanya perjanjian kerja di kasus tersebut antara sdr. T dengan CN dan DD sebagai bosnya dikasus tersebut yang memperkerjakan anak dibawah umur.

Seperti diketahui dalam duduk kasus posisi tersebut, bahwa korban yaitu, CN dan DD yang masing-masing berusia 14 Tahun tersebut waktu itu bekerja berjualan cobek bersama Terdakwa T untuk membantu perekonomian keluarganya karena mereka berasal dari keluarga yang tidak mampu. Dan mereka bekerja dengan terdakwa juga berdasarkan keinginan mereka sendiri dan tidak adanya unsur paksaan maupun kekerasan fisik.

Perjanjian kerja yang dibuat oleh Terdakwa T dengan CN Dan DD selaku korban ialah secara Lisan. Dan menurut Undang-undang 13 Tahun 2003 tentang Ketenagakerjaan, pasal 51 yang berisi :

1. Perjanjian kerja dibuat secara tertulis atau lisan.

2. Perjanjian kerja yang dipersyaratkan secara tertulis dilaksanakan sesuai dengan peraturan perundangundangan yang berlaku.

Oleh karena itu perjanjian kerja mereka itu berlaku sehingga menjadi hubungan kerja.

Selanjutnya Pasal 52 Undang-Undang Nomor 13 tahun 2003 yang berisi :

(1) Perjanjian kerja dibuat atas dasar:

a. kesepakatan kedua belah pihak;

b. kemampuan atau kecakapan melakukan perbuatan hukum;

c. adanya pekerjaan yang diperjanjikan; dan

d. pekerjaan yang diperjanjikan tidak bertentangan dengan ketertiban umum, kesusilaan, dan peraturan perundang-undangan yang berlaku.

(2) Perjanjian kerja yang dibuat oleh para pihak yang bertentangan dengan ketentuan sebagaimana dimaksud dalam ayat (1) huruf a dan b dapat dibatalkan. 
(3) Perjanjian kerja yang dibuat oleh para pihak yang bertentangan dengan ketentuan sebagaimana dimaksud dalam ayat (1) huruf c dan d batal demi hukum.

Sudah jelas bahwa jika salah satu dari point pasal 52 ayat 1 tidak terpenuhi maka perjanjian kerja tersebut Batal demi hukum. Dalam kasus yang dibahas oleh penulis, CN dan DD dalam membuat perjanjian kerja dengan terdakwa masih berusia 14 Tahun, artinya mereka tidak cakap dalam melakukan perbuatan Hukum, sehingga dapat membuat hubungan kerja yang dibuat oleh mereka batal demi Hukum.

Namun dalam pasal 68 undangundang 13 Nomor 2003 tentang ketenagakerjaan memang di situ berisi bahwa "Pengusaha dilarang mempekerjakan anak", akan tetapi jikalau melihat dan meninjau pasal 69 Sampai pasal 75 undang-undang Nomor 13 Tahun 2003 tentang ketenagakerjaan, Anak boleh bekerja dan menjalin hubungan kerja tetapi dengan memperhatikan hak dan kewajiban yang harus didapatkan dan diperhatikan dalam perkembangan Anak.

Pasal-pasal tersebut adalah:

Pasal 69

(1) Ketentuan sebagaimana dimaksud dalam Pasal 68 dapat dikecualikan bagi anak yangberumur antara 13 (tiga belas) tahun sampai dengan 15 (lima belas) tahun untuk melakukan pekerjaan ringan sepanjang tidak mengganggu perkembangan dan kesehatan fisik, mental,dan sosial.

(2) Pengusaha yang mempekerjakan anak pada pekerjaan ringan sebagaimana dimaksuddalam ayat (1) harus memenuhi persyaratan:

a. izin tertulis dari orang tua atau wali;

b. perjanjian kerja antara pengusaha dengan orang tua atau wali; c. waktu kerja maksimum 3 (tiga) jam;

d. dilakukan pada siang hari dan tidak mengganggu waktu sekolah;

e. keselamatan dan kesehatan kerja;

f. adanya hubungan kerja yang jelas; dan

g. menerima upah sesuai dengan ketentuan yang berlaku.

(3) Ketentuan sebagaimana dimaksud dalam ayat (2) huruf a, b, f, dan $g$ dikecualikan bagi anakyang bekerja pada usaha keluarganya.

Pasal 70

(1) Anak dapat melakukan pekerjaan di tempat kerja yang merupakan bagian dari kurikulum pendidikan atau pelatihan yang disahkan oleh pejabat yang berwenang.

(2) Anak sebagaimana dimaksud dalam ayat (1) paling sedikit berumur 14 (empat belas) tahun.

(3) Pekerjaan sebagaimana dimaksud dalam ayat (1) dapat dilakukan dengan syarat:

a. diberi petunjuk yang jelas tentang cara pelaksanaan pekerjaan serta bimbingan danpengawasan dalam melaksanakan pekerjaan dan

b. diberi perlindungan keselamatan dan kesehatan kerja.

Pasal 71

(1) Anak dapat melakukan pekerjaan untuk mengembangkan bakat dan minatnya.

(2) Pengusaha yang mempekerjakan anak sebagaimana dimaksud dalam ayat (1) wajibmemenuhi syarat:

a. di bawah pengawasan langsung dari orang tua atau wali;

b. waktu kerja paling lama 3 (tiga) jam sehari; dan

c. kondisi dan lingkungan kerja tidak mengganggu perkembangan fisik, mental, sosial,dan waktu sekolah. 
(3) Ketentuan mengenai anak yang bekerja untuk mengembangkan bakat dan minat sebagaimana dimaksud dalam ayat (1) dan ayat (2) diatur dengan Keputusan Menteri.

Pasal 72

Dalam hal anak dipekerjakan bersamasama dengan pekerja/buruh dewasa, maka tempat kerjaanak harus dipisahkan dari tempat kerja pekerja/buruh dewasa.

Pasal 73

Anak dianggap bekerja bilamana berada di tempat kerja, kecuali dapat dibuktikan sebaliknya.

Pasal 74

(1) Siapapun dilarang mempekerjakan dan melibatkan anak pada pekerjaanpekerjaan yangterburuk.

(2) Pekerjaan-pekerjaan yang terburuk yang dimaksud dalam ayat 1 meliputi:

a. segala pekerjaan dalam bentuk perbudakan atau sejenisnya;

b. segala pekerjaan yang memanfaatkan, menyediakan, atau menawarkan anak untuk pelacuran, produksi pornografi, pertunjukan porno, atau perjudian;

c. segala pekerjaan yang memanfaatkan, menyediakan, atau melibatkan anak untukproduksi dan perdagangan minuman keras, narkotika, psikotropika, dan zat adiktif lainnya; dan/atau;

d. semua pekerjaan yang membahayakan kesehatan, keselamatan, atau moral anak.

(3) Jenis-jenis pekerjaan yang membahayakan kesehatan, keselamatan, atau moral anak sebagaimana dimaksud dalam ayat (2) huruf d ditetapkan dengan Keputusan Menteri.
Pasal 75

(1) Pemerintah berkewajiban melakukan upaya penanggulangan anak yang bekerja di luarhubungan kerja.

(2) Upaya penanggulangan sebagaimana dimaksud dalam ayat (1) diatur dengan Peraturan Pemerintah.

Jika dilihat dari kasus yang dialami $\mathrm{CN}$ dan DD dengan terdakwa T, bahwa benar $\mathrm{CN}$ tidak menerima hak yang seharusnya mereka dapatkan seperti jam kerja, faktor kesehatan, ruang kerja, dan lain lain yang mengganggu perkembangan mental dan moral anak sesuai dengan pasal 69 sampai pasal 75 undang-undang 13 tahun 2003 tentang Ketenagakerjaan yang tertera di atas.

Dan terdakwa seharusnya didakwa dan dihukum menurut aturan hukum yang berlaku dalam Undang-Undang Nomor 13 Tahun 2003 ini sesuai dengan pasal Pasal 183 yang berisi :

(1) Barang siapa melanggar ketentuan sebagaimana dimaksud dalam Pasal 74, dikenakansanksi pidana penjara paling singkat 2 (dua) tahun dan paling lama 5 (lima) tahun dan/atau denda paling sedikit Rp 200.000.000,00 (dua ratus juta rupiah) dan paling banyak Rp. 500.000.000,00 (lima ratus juta rupiah).

(2) Tindak pidana sebagaimana dimaksud dalam ayat (1) merupakan tindak pidana kejahatan.

Alasan seperti yang tertera di ataslah, menurut penulis Terdakwa T sudah memperkerjakan dan melibatkan anak pada pekerjaan pekerjaan yang terburuk sehingga membahayakan kesehatan, keselamatan atau moral anak dengan berdasar juga pada Keputusan Menteri Tenaga Kerja dan Transmigrasi Republik Indonesia Nomor 235/MEN/2003 tentang Jenis-Jenis Pekerjaan yang Membahayakan Kesehatan, Keselamatan, atau Moral Anak. 


\section{PENUTUP}

Pertimbangan Hakim dalam menjatuhkan Tindak Pidana dalam kasus Tindak Pidana Perdagangan Orang yang dilakukan Perseorangan Kepada Anak di bawah umur berdasarkan Putusan Nomor 1608/PID.SUS/2016/PN.TNG ialah ada yang menyimpan kekeliruan.

Karena menurut Penulis, Hakim dalam pertimbangannya beranggapan bahwa tindakan saksi CN dan DD, berjualan cobek didasari atas keinginannya sendiri dan juga melakukan pembelajaran melalui model yaitu lingkungan sosial. Padahal menurut penulis, bahwa sudah jelas tertera dalam pasal 26 Undangundang Nomor 21 tahun 2007 tentang Pemberantasan Tindak Pidana Perdagangan Orang yang berisi :

"Persetujuan Korban perdagangan orang tidak menghilangkan penuntutan tindak pidana perdagangan orang”. Sehingga seharusnya undang-undang tersebut seharusnya saling berkaitan pasal demi pasal untuk menjadi bahan pertimbangan dalam memutus perkara yang seadil-adilnya oleh Para Majelis Hakim.

Bentuk Penerapan Hukum yang ditujukan kepada terdakwa $\mathrm{T}$ dengan mengadili bahwa Perbuatan Terdakwa itu tidak merupakan suatu tindak Pidana dan Melepaskan Terdakwa Tajudin Bin Tatang Rusmana dari segala tuntutan Hukum oleh Majelis Hakim ialah sangat tepat. Karena jika ditinjau dari tinjauan yang ingin dicoba analisis oleh penulis, perbuatan tedakwa tidak memenuhi unsur dari pada Tindak Pidana Perdagangan Orang.

Dan menurut penulis seharusnya tindakan terdakwa tersebut lebih dikaitkan dengan Hukum Ketenagakerjaan, karena menyangkut paut perjanjian kerja dalam kasus tersebut sehingga menimbulkan Hak dan kewajiban antara Terdakwa Tajudin Bin Tatang Rusmana dengan korban selaku CN dan DD yang masih di bawah Umur.

Sebaiknya dalam kasus yang dialami oleh sdr. CN dan DD, Hakim dalam pertimbangannya tidak mengesampingkan hak mereka sebagai anak di bawah umur. Sehingga walaupun anak tersebut setuju untuk bekerja, Hakim sebaiknya tetap memperhatikan hak yang harus diperoleh anak dalam perundang-undangan yang berlaku di Indonesia. Dan dalam kasus yang mempekerjakan Anak di bawah umur ini menjadi perhatian yang sangat penting bagi pemerintah untuk melindungi perkembangan anak dalam berkembang. jikalau melihat kasus berdasarkan Putusan Nomor 1608/PID.SUS/ 2016/PN.TNG yang dalam putusannya menyatakan perbuatan terdakwa merupakan suatu Tindak Pidana itu tidak akan tidak terjadi lagi, karena perbuatan tersebut menyalahi aturan dalam memperkerjakan anak dan ada akibat hukumnya berupa Pidana Penjara dan Pidana denda.

Dalam hal penerapan Hukum terhadap terdakwa sebaiknya pihak yang terkait melalui badan-badan Hukum yang berwenang lebih jeli melihat duduk kasus yang terjadi agar penerapan terhadap perseorang yang memperkerjakan Anak di bawah umur yang menyalahi aturan agar menerima hukuman yang setimpal oleh karena perbuatannya. Dan Perlunya pengetahuan serta peran para stakeholders dalam rangka perkembangan anak, sehingga mereka yang ingin memperkerjakan anak dengan alasan membantu taraf ekonomi keluarga itu tahu cara main aturannya menurut perundangundangan yang berlaku di Indonesia. 


\section{DAFTAR PUSTAKA}

\section{A. Literatur}

Ali, Mahrus dan Bayu Aji Pramono, Perdagangan Orang: Dimensi, Instrumen Internasional dan Pengaturannya di Indonesia, Citra Aditya Bakti, Bandung, 2011.

Arief, Barda Nawawi, Perkembangan Sistem Pemidanaan di Indonesia, bahan Penataran Nasional Hukum Pidana dan Kriminologi VII, di UBAYA, 2005, diterbitkan oleh Penerbit Pustaka Magister, Semarang, 2007.

Atmasasmita, Romli, Pengantar Hukum Pidana Internasional, Refika Aditama, Bandung, 2003.

Fajar, Mukti dan Yulianto Achmad, Dualisme Penelitian Hukum Normatif dan Empiris, Pustaka Pelajar, Yogyakarta, 2010.

Chazawi, Adami. 2005. Tindak Pidana Mengenai Kesopanan. Jakarta: Penerbit PT. Raja Grafindo Persada

Ghufran H. Kordi K.M. 2010. Hak dan Perlindungan Anak Di Atas Kertas. Jakarta: Penerbit PT.Perca.

Gosita, Arif. 2007. Masalah Korban Kejahatan. Jakarta: FHUI

\section{B. Perundang-undang}

Undang-Undang Dasar Negara RI Tahun 1945.

TAP MPR Nomor XVII Tahun 1998 Tentang Hak Asasi Manusia (HAM)
Undang-Undang Nomor 39 Tahun 1999 Tentang Hak Asasi Manusia (HAM)

Undang-Undang Nomor 21 Tahun 2007 Tentang Pemberantasan Tindak Pidana Perdagangan Orang

Undang-Undang Nomor 35 Tahun 2014 jo Undang-Undang Nomor 23 Tahun 2002 Tentang Perlindungan Anak.

Undang-Undang Nomor 31 Tahun 2014 jo Undang-Undang Nomor 13 Tahun 2006 Tentang Perlindungan Saksi dan Korban KUHP KUHAP (Undang-Undang Nomor 8 Tahun 1981) 